\title{
The Effect of External, Internal and Managerial Risk on Firm Value
}

\author{
Elga Nurhikmah", Erna Setiany \\ Master Program in Accounting, Universitas Mercu Buana, Jakarta, Indonesia
}

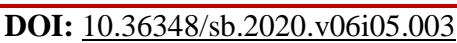 \\ | Received: 11.05.2020 | Accepted: 18.05.2020 | Published: 21.05.2020 \\ *Corresponding author: Elga Nurhikmah
}

\section{Abstract}

The purpose of this study is to examine the effect of external, internal and managerial risks on firm value. External risk is proxied by carbon emissions disclosure and environmental performance, internal risk is proxied by enterprise risk management disclosure, while managerial risk is proxied by leverage. The study was conducted on non-service industry companies listed on the Indonesia Stock Exchange. The sampling technique used was purposive sampling, with criteria for companies that had a PROPER rating for the 2017 and 2018 periods of 64 companies. The results showed that the PROPER rating and leverage affect on firm value, while the carbon emissions disclosure and enterprise risk management disclosure do not affect on firm value. The inability to prove the effect of both disclosures can be caused by the element of subjectivity in its measurement. This result proves that investors take into account external risks in the form of environmental performance based on PROPER ratings and leverage as manifestations of managerial risk. Thus, the results of this study prove that investors recognize the accountability and independence of PROPER assessments.

Keywords: Carbon emission disclosure, environmental performance, enterprise risk management disclosure, leverage, firm value.

Copyright @ 2020: This is an open-access article distributed under the terms of the Creative Commons Attribution license which permits unrestricted use, distribution, and reproduction in any medium for non-commercial use (NonCommercial, or CC-BY-NC) provided the original author and source are credited.

\section{INTRODUCTION}

A country's economic growth in principle describes the economic development, economic prosperity and changes in a country's economic fundamentals in the long term. One driving factor is the development of the capital market which is influenced by the development of the companies in it. The company's main goal is to increase firm value which is an achievement and make the market believe in the company's performance, so that the company is seen as having good future prospects.

Brigham and Erhardt [1], Juwita [2], firm value is the result of company performance. A higher firm value implies a higher share which ultimately increases shareholder wealth. Increasing of firm value is an achievement for the company, because it will make the welfare of the owners also increase.

If you look at the reality at this time, based on sources obtained that there are 8 companies that went bankrupt in 2017 at the Central Jakarta Commercial Court. The bankruptcy was caused by not being able to pay its debts (source: berita24.bisnis.com). On
December 28, 2018 BEI officially imposed the I-Suite program or giving special marks to listed companies with the problematic number of 35 companies (source: cnnindonesia.com). Based on data from the Central Statistics Agency in 2018 Indonesia's economic growth will reach $5.17 \%$. In the fourth quarter, the processing industry grew by $4.25 \%$, but when compared to the third quarter it was $4.35 \%$, this growth could be said to be lower (source: national.kontan.co.id).

Firm value implies investors' perceptions of good or bad management in managing the company. There are risks that may affect firm value including external risks seen from environmental factors such as carbon emissions disclosure and environmental performance, internal risks seen from enterprise risk management disclosure and managerial risk seen from leverage. Kelvin et al., [3] suggested that the company's image can be improved, the company should pay more attention to the relationship between the company and the surrounding environment because the company's sustainability must combine economic performance, concentration of social justice and responsibility for environmental preservation. Carbon emission disclosure can be good news for investors because it means the 
investment risk is low, as research by Anggraeni [4], Kelvin et al., [3] and Gabrielle and Toly [5], carbon emissions disclosure has a positive effect on firm value. In contrast to Iskandar and Fran [6], the wider of carbon emissions disclosure, the lower of firm value because investors indirectly punish companies that disclose their carbon emissions, but heavier penalties will be imposed on companies that do not submit information related to their emissions because the government will give sanctions.

In an effort to preserve the environment, the Ministry of Environment and Forestry of the Republic of Indonesia ranks an award for environmental performance by the company, which is the Corporate Performance Rating Program (PROPER) in environmental management, so that when the company gets a rating that states the company has a good environmental performance, it will cause a positive response related to firm value. Anggraeni [4] states that firm value that are rated PROPER gold is higher than companies that are rated PROPER red. Kumar and Shetty [7] revealed that the number of voluntary environmental programs implemented by a company has a positive relationship to the firm market value. Khlif [8], social and environmental disclosure has a significant positive effect on company performance. However, according to Sarumpaet et al., [9], deteriorating environmental performance is associated with higher prices, whereas lower environmental performance is a value that is not relevant to the market.

In the practice of corporate risk disclosure, managers must disclose information about the risks faced by the company in their financial statements. Through enterprise risk management disclosure, it is expected that the company will be assessed well by investors because they have carried out risk management, so as to increase the firm value. Empirical evidence from Bravo [10] shows that the disclosure of information about risk is positively related to firm value, this evidence is very important to understand the usefulness of disclosing information about risk in dialogue between the company and its stakeholders. Louhichi and Zreik [11] states the disclosure of risk information is part of a social contract that must be valued with good reputation. Devi et al., [12] found that enterprise risk management disclosure can minimize information asymmetry that can harm stakeholders. Agustina and Baroroh [13] have the opposite view, they reviewed 53 banking companies and the results show that the implementation of Enterprise Risk Management does not have a significant influence on firm value because the implementation tends to fulfill obligations only in Bank Indonesia regulations.

Devi et al., [12] explains that leverage is a funding policy related to the company's decision to finance the company through external parties or creditors, so that the company is obliged to pay the principal and interest of the loan. The greater the leverage, the greater the investment risk, and vice versa. Duais [14], there is a positive relationship between financial leverage and company performance and the positive impact caused by a mixture of long-term and short-term debt (using total debt), on the other hand, short-term debt has a negative relationship and has an impact on company performance. Mishra and Kapil [15] states that it is cheaper to manage resources through internal means than through the debt market. Contrary to the research results of Rudangga and Sudiarta [16] that the use of leverage if related to tax calculations is able to increase the firm value, because the interest charged on debt will be deducted first, which will ease the company's tax. Alkhazaleh and AlEitan [17] and Hasibuan et al., [18] also states that leverage has a significant positive effect on firm value.

This study aims to reconfirm previous research related to how the influence of external risk as proxied by carbon emissions disclosure and environmental performance, how the influence of internal risk as proxied by enterprise risk management disclosure, and how the influence of managerial risk as proxied by leverage on firm value by using measures company as a control variable.

\section{LITERATURE STUDY AND HYPOTHESES Agency Theory}

According to Hill and Jones [19], agency theory is a collection of contracts found in companies. Jensen and Meckling [20] mention agency theory as a contractual relationship between principals, namely the shareholders who are responsible for the duties and authority of agents or commonly referred to as managers in making decisions regarding the existence of agreed work contracts. This theory arises because of the possibility that there is a conflict caused by the separation of ownership and operational management of the company. Conflicts occur in the form of information asymmetry so that management has an interest in giving signals about its performance, both internal, external or managerial performance.

\section{Legitimacy Theory}

Legitimacy theory underlies the incentives of entities that voluntarily disclose reports on social and environmental responsibility [21, 22, 4]. Nasi et al., [23]; Suhardjanto et al., [24] mentioned that the theory of legitimacy is the recognition of the public for companies regarding corporate social responsibility. Legitimacy will be threatened if there is a gap between public expectations and the company's ability to meet those expectations. The environmental responsibility report in the form of carbon emissions disclosure and environmental performance is an effort of the company to report its performance which not only explores, but controls and protects nature and the environment. Risk 
disclosure also becomes part of the company's efforts to foster the trust of stakeholders. These disclosures are expected to help create added value for the company in order to remain sustainable in conducting its business [24].

\section{Carbon Emission Disclosure}

Carbon gas emission is the release of carbon into the atmosphere as a result of ignition of fossil fuels, which is directly related to the release of carbon dioxide into the atmosphere, resulting in rapid global warming $[25,26]$. One contributor to the carbon footprint is the company's operational activities. Companies are expected to disclose their activities that contribute to increasing climate change, one of which is carbon emissions disclosure [6]. Carbon emissions disclosure was measured using an index developed by Choi et al., [27] constructed from the Carbon Disclosure Project (CDP) request sheet and there are five broad categories related to climate change and carbon emissions, namely: 1) calculation of greenhouse gas emissions; 2) climate change: risks and opportunities; 3) calculation of energy consumption; 4) reduction and cost of greenhouse gases; and 5) accountability for carbon emissions. A total of 18 disclosure items were used to measure the level of carbon emissions disclosure.

Anggraeni [4] states the disclosure of GHG emissions has a positive effect on firm value, meaning that the market responds to information related to the company's efforts in managing GHG emissions. Kelvin et al., [3] and Gabrielle and Toly [5], carbon emissions disclosure has a significant positive effect on firm value. The higher the level of carbon emissions disclosure, the higher the firm value.

In contrast to Iskandar and Fran [6], carbon emissions disclosure is negatively correlated and significantly influences firm value. The more extensive the carbon emissions disclosure by companies, the lower of firm value and vice versa. This shows that investors indirectly punish companies that disclose their carbon emissions, but heavier penalties will be imposed on companies that do not submit information related to their emissions because the government will impose sanctions.

The first hypothesis proposed in this study is:

Hypothesis 1: Carbon emissions disclosure has a positive effect on firm value.

\section{Environmental Performance}

Environmental performance assessment is measured using the PROPER rating conducted by the Ministry of Environment and Forestry of the Republic of Indonesia which aims to improve the company's performance in environmental conservation. Nurlis [28] stated that the PROPER rating would describe the company as having a more active level of environment and indirectly the company would take the initiative to disclose environmental information voluntarily. The company's concern for the environment can provide added firm value.

Gabrielle and Toly [5] found that environmental performance had a significant positive effect on firm value. The better the environmental performance of a company, the higher the value of the company. Kumar and Shetty [7], the number of voluntary environmental programs implemented by a company has a positive relationship to the company's market value. Khlif [8] states social and environmental disclosure has a significant positive effect on company performance. Anggraeni [4], a company that discloses environmental performance will provide positive information to investors so that it will increase the value of the company. But Sarumpaet et al., [9] states that deteriorating environmental performance is associated with higher prices, whereas lower environmental performance is a value that is not relevant to the market.

The second hypothesis proposed in this study is:

Hypothesis 2: Environmental performance has a positive effect on firm value.

\section{Enterprise Risk Management Disclosure}

In September 2004, the Committee of Sponsoring Organizations (COSO) published ERM as a corporate risk management process that was designed and implemented into every corporate strategy to achieve corporate objectives. The COSO "ERM Integrated Framework" [29], by far, is the most widely accepted framework and is used as a standard to comply with regulated and approved internal control, risk management and reporting requirements. This comes from the way management runs the company and is integrated with the management process [30].

The ERM framework includes 108 ERM disclosure items covering eight components, including: 1) the internal environment; 2) setting goals; 3) identification of events; 4) risk assessment; 5) response to risk; 6) control activities; 7) information and communication; and 8) monitoring [29, 31, 12]. These eight components are needed to achieve the company's objectives which include strategic, operational, financial reporting, and compliance with statutory provisions. Companies that carry out enterprise risk management disclosure indicate that the company has used a comprehensive approach in managing company risk, increasing the ability to manage uncertainty, minimizing threats, maximizing opportunities and having a competitive advantage [12].

Empirical evidence from Bravo [10] shows that disclosure of information about risk is positively related to firm value. Louhichi and Zreik [11] also highlighted risk reporting affecting the company's 
reputation positively so that the more companies disclose risk information, the more it promotes company reputation. Contrary to Agustina and Baroroh [13] which states that the implementation of Enterprise Risk Management (ERM) does not have a significant effect on firm value because the implementation tends to fulfill obligations only on Bank Indonesia regulations, besides that qualitative reporting is considered more difficult to compare each other so that investors don't focus too much on that.

The third hypothesis proposed in this study is:

Hypothesis 3: Enterprise risk management disclosure has a positive effect on firm value.

\section{Leverage}

According to Horne and Wachowicz [32], leverage ratios are used to measure the extent to which a company can be financed by debt. Rudangga and Sudiarta [16], companies that are over in using financing with debt, are considered unhealthy because it can reduce company profits. The use of debt tends to increase the potential for financial difficulties. Therefore, this leverage is generally the concern of investors in assessing the company, whether it has good prospects or not.
In line with the results of Duais research [14], that short-term debt has a negative relationship on firm performance. Mishra and Kapil [15], it is cheaper to manage resources through internal than through the debt market. Contrary to Rudangga and Sudiarta [16], leverage has a positive effect on firm value. The higher the company uses funding from debt, the higher the firm value. Alkhazaleh and Al-Eitan [17] and Hasibuan et al., [18] also states that leverage has a significant effect on firm value.

The fourth hypothesis proposed in this study is:

Hypothesis 4: Leverage has a negative effect on firm value.

\section{RESEARCH METHODS}

The population of this research is non service industry companies listed on the Indonesia Stock Exchange during the 2017 and 2018 periods totaling 250 companies. The sampling technique used was purposive sampling, with criteria for companies that had a PROPER rating for the 2017 and 2018 periods of 64 companies. The period of this research is two years, so the amount of data is 128 observational data.

The following is a summary of operating the variables in tabular form.

Table 1. Variable Operationalization

\begin{tabular}{|c|c|c|}
\hline Variables & Indicator & References \\
\hline Firm Value & Tobin's Q $=\frac{(\mathrm{MVS}+\mathrm{D})}{\mathrm{TA}}$ & Chung and Pruit (1994) \\
\hline $\begin{array}{l}\text { Carbon Emissions } \\
\text { Disclosure }\end{array}$ & $\begin{array}{l}\text { Carbon Emissions Disclosure } \\
=\left(\frac{\sum \text { disclosure item }}{\text { maximum disclosure item }}\right) \times 100 \%\end{array}$ & (Choi, et al., 2013) \\
\hline $\begin{array}{l}\text { Environmental } \\
\text { performance }\end{array}$ & $\begin{array}{l}\text { PROPER rank, consisting of: } \\
\text { a) Gold = Very Good; Score }=5 \\
\text { b) Green = Extraordinary; Score }=4 \\
\text { c) Blue = Good; Score }=3 \\
\text { d) Red = Bad; Score }=2 \\
\text { e) Black = Very Bad; Score }=1\end{array}$ & $\begin{array}{l}\text { PROPER from the } \\
\text { Ministry of Environment } \\
\text { and Forestry of the } \\
\text { Republic of Indonesia }\end{array}$ \\
\hline $\begin{array}{l}\text { Enterprise Risk } \\
\text { Management Disclosure }\end{array}$ & ERMD $=\frac{\sum \text { risk diclosure items }}{\text { maximum diclosure item }} \times 100 \%$ & COSO (2004) \\
\hline Leverage & $\mathrm{DER}=\frac{\text { Total Liabilities }}{\text { Total Equity }}$ & $\begin{array}{l}\text { Horne dan Wachowicz } \\
\qquad(2012)\end{array}$ \\
\hline Firm Size & Size $=$ Ln Total Assets & Munawir (2010) \\
\hline
\end{tabular}

\section{RESULTS AND DISCUSSION \\ Descriptive Statistical Analysis}

Descriptive statistical analysis aims to provide a descriptive description of the data that includes maximum, minimum and mean. Table- 2 below shows the results of descriptive statistics from the research variables namely Company Value (TQ), Carbon Emission Disclosure (CED), Environmental Performance (PROPER), Enterprise Risk Management Disclosure (ERMD) and Leverage (DER). 
Table 2. Descriptive Statistics of Research Variables

\begin{tabular}{lccccc}
\hline & TQ & CED & PROPER & ERMD & DER \\
\hline Maximum & 4.93139 & 100 & 5 & 73.1482 & 2.87719 \\
\hline Minimum & 0.43081 & 0 & 2 & 48.1482 & 0.09059 \\
\hline Mean & 1.43883 & 28.6892 & 3.0625 & 59.9031 & 0.92308 \\
\hline Observations & 128 & 128 & 128 & 128 & 128 \\
\hline
\end{tabular}

Based on Table-2, it is known that the sample company with the highest value (overvalued) is Kalbe Farma Tbk. (KLBF) in 2017 amounted to 4.93 times the book value of its assets and the company that has the lowest company value (undervalued), namely Polychem Indonesia Tbk. (ADMG) and Mustika Ratu Tbk. (MRAT) in 2018 amounting to 0.43 times the book value of its assets.

On average the sample companies have carried out Carbon Emission Disclosures (CED) of $28.69 \%$, carbon emissions disclosure conducted is still at a simple stage, although there are sample companies that have $100 \%$ revealed their carbon emissions, namely Vale Indonesia Tbk. (INCO), Indocement Tunggal Prakarsa Tbk. (INTP) and Semen Indonesia (Persero) Tbk. (SMGR) in 2017 and 2018, however, many sample companies did not disclose carbon emissions (0\%) during the study period, namely 23 companies. When viewed on a per item disclosure basis, out of 18 items, some companies have disclosed related risk assessments in climate change and actions taken to manage risks, the methodology used to calculate GHG emissions (for example, GHG Protocol or ISO), coverage 1,2 and 3 direct GHG emissions, GHG emissions by source, GHG emissions by facility or segment, quantification of energy used from renewable sources then disclosed by type, facility or segment, describes detailed plans or strategies to reduce GHG emissions, has a board committee responsible for all actions related to climate change and describe the mechanism of the board in reviewing the company's progress related to climate change. Whereas for some of these disclosures, only less than 15 companies disclosed them, including related to the assessment of financial implications, business implications and opportunities for climate change, external verification of the amount of GHG emissions, including its relation to disclosure of total GHG emissions, comparison of GHG emissions with previous years, total energy consumed, specification of target levels and target years for GHG emission reduction, emission reduction and savings achieved to date as a result of the reduction plan and future emission costs are taken into account in capital expenditure planning. This is due to the lack of calculation standards set by regulators, so many companies report only disclosure.
Sample companies that achieved rank 5 (Gold) or had very good environmental performance were 2 companies, namely in 2017 including Medco Energi Internasional Tbk. (MEDC) and Bukit Asam Tbk. (PTBA). The companies that have outstanding environmental performance (Green) are 8 companies in 2017 and 6 companies in 2018. Most of the sample companies have a PROPER rating of 3 (Blue), known in 2017 and 2018 there are 49 companies and 53 companies respectively. Sample companies that reached rank 2 (Red) or had poor environmental performance were 5 companies including Gajah Tunggal Tbk. (GJTL), KMI Wire \& Cable Tbk. (KBLI), Kabelindo Murni Tbk. (KBLM), Martina Berto Tbk. (MBTO) and Mustika Ratu Tbk. (MRAT). In this study sample there were no companies rated PROPER 1 (Black) or had very poor environmental performance.

The highest sample companies conducted Enterprise Risk Management Disclosure, respectively in 2017 and 2018, amounting to $73.15 \%$, was Austindo Nusantara Jaya Tbk. (ANJT), while the lowest sample company in disclosing the risk that is $48.15 \%$ is Indospring Tbk. (INDS) in 2018. Based on the risk disclosure data seen from the component (1) internal environment, in 2017 there were $77.44 \%$ of companies and in 2018 there were $78.97 \%$ of companies; (2) Goal setting, in 2017 there were $75.33 \%$ companies and in 2018 there were $82.22 \%$ companies; (3) Event identification, in 2017 there were $52.37 \%$ of companies and in 2018 there were $54.45 \%$ of companies; (4) Risk assessment, in 2017 there were $50.83 \%$ of companies and in 2018 there were $52.64 \%$ of companies; (5) Risk response, in 2017 there were $53.90 \%$ of companies and in 2018 there were $55.08 \%$ of companies; (6) Control activities, in 2017 there were $63.62 \%$ of companies and in 2018 there were $67.05 \%$ of companies; (7) Information and communication, in 2017 there were $85.78 \%$ of companies and in 2018 there were $92.44 \%$ of companies; and (8) Monitoring, there were $67.56 \%$ of companies both in 2017 and 2018. This proves that the risk disclosure and management conducted by non sample service industry companies are still low, while good internal control is if the disclosure is $100 \%$ or at least $90 \%$. 
Elga Nurhikmah \& Erna Setiany., Sch Bull, May., 2020; 6(5): 131-138

Companies that have a high DER value of 2.88 times, namely Surya Esa Perkasa Tbk. (ESSA) in 2017, there are companies that have a very low DER of 0.09 times, namely Tifico Fiber Indonesia Tbk. (TFCO) in 2018. If seen from the average sample company has a leverage (DER) of 0.92 times, it means that most companies can still pay off all their debts / liabilities with the assets they have.

This research has passed the classical assumption test including multicollinearity and normality tests. Multicollinearity test uses an independent correlation variable matrix, and the results do not have an independent correlation variable above 0.90 so that this study does not contain multicollinearity. Normality test uses the Jarque Bera test with the JB value of 4.740420 and is significant with a probability value of 0.093461 or prob> 0.05 , so that the residuals are normally distributed.

The following is the output of the estimated panel data regression model used in the study.

Table 3. Panel Data Regression Model

\begin{tabular}{cccc}
\hline \hline Variable & Coefficient & Prob. & Conclusion * \\
\hline C & -0.570957 & 0.6411 & \\
CED & 0.001262 & 0.4670 & Not Significant \\
ERMD & 0.335619 & 0.0020 & Significant \\
DER & -0.016932 & 0.1201 & Not Significant \\
SIZE & -0.166602 & 0.0438 & Significant \\
R-squared & 0.028958 & 0.4662 & Not Significant \\
Adjusted R-squared & 0.148235 & & \\
SE of regression & 0.532025 & & \\
F-statistic & 5.420435 & & \\
Prob (F-statistic) & 0.000154 & & \\
Durbin-Watson stat & 0.248863 & & \\
Total panel (balanced) observations: 128 & \\
\hline \hline Source: Data Processing Eviews 10 & & \\
TQ = - 0,570957 + 0,001262CED + 0,335619PROPER - 0,016932ERMD - 0,166602DER + \\
0,028958SIZE + e
\end{tabular}

Based on Table-3, investor assessment of PROPER is more dominant compared to other disclosures such as carbon emissions disclosure and enterprise risk management disclosure. PROPER is assessed by institutions that are already professional and recognized, compared to carbon emissions disclosure. Investors can immediately see how the company's responsibility to the environment through PROPER ratings owned by the company. Internal risk which is proxied by ERMD is not given enough attention by investors because it is related to direct risk within the company.

In Table-3, the probability for the ERMD variable is $12 \%$, meaning that if the error is $15 \%$ then the hypothesis can be accepted. The coefficient value in the regression equation that is formed obtained negative results, meaning that the company is concerned with internal risks but still has an error of $15 \%$.

\section{DISCUSSION}

Carbon emissions disclosure has no effect on firm value. Generally, investors' understanding of carbon emission disclosures is not good enough, this is because in the calculation there is no standard set by the regulator, so that the implementation in the disclosure of corporate carbon emissions is still at an early stage, as evidenced when a descriptive analysis is based on disclosure items, only a portion of the companies disclose carbon emissions, in addition there are several items of disclosure that even only a few companies do the disclosure. In contrast to the results of research 
Anggraeni [4], Kelvin et al., [3] and Gabrielle and Toly [5], disclosure of GHG emissions has a positive effect on firm value. Iskandar and Fran [6], carbon emissions disclosure is negatively correlated and significantly influences firm value. Thus this study does not provide support for agency theory and legitimacy theory.

Environmental performance has a significant positive effect on firm value. Investors can compare the company's performance in environmental conservation through the PROPER rating because investors recognize the accountability and independence of the PROPER assessment from the Ministry of Environment and Forestry of the Republic of Indonesia. The better the ranking proves that the company is increasingly concerned about the environment by getting involved both directly in its preservation and in the activities of the surrounding environment, thus triggering the attention and interest of investors to invest which then adds firm value. This result is in line with Gabrielle and Toly [5], environmental performance has a significant positive effect on firm value. Neither are Kumar and Shetty [7], Khlif [8] and Anggraeni [4]. But it is different from Sarumpaet et al., (2017), deteriorating environmental performance is associated with higher prices, whereas lower environmental performance is a value that is not relevant to the market. Thus this research provides support for agency theory and legitimacy theory.

Enterprise risk management disclosure has no effect on firm value. The risk disclosure made by the non-service industry company which is the sample of this study is still low, because the internal control should be at $100 \%$ and the lowest at $90 \%$. This proves that the risk management carried out by the company both in managing risk and disclosing it is still low, so it does not provide added firm value. In addition, the inability to prove the effect of the disclosure can be caused by an element of subjectivity in its measurement. In line with the results of Agustina and Baroroh's research [13] that the implementation of Enterprise Risk Management (ERM) does not have a significant effect on firm value. However, it is different from the results of Bravo [10], Louhichi and Zreik [11] and Devi et al., [12] which states that there is a positive and significant effect of ERM disclosure on firm value. Thus this study does not provide support for agency theory and legitimacy theory.

Leverage has a significant negative effect on firm value. Companies that use debt are likely to increase the potential for financial difficulties in the future. Generally, this leverage is a concern of investors in assessing the company, because leverage is considered as a manifestation of managerial risk. The higher the debt a company has, the lower its value and vice versa. In line with the results of Duais research [14], short-term debt has a negative relationship on company performance. Mishra and Kapil [15], it is cheaper to manage resources through internal than through the debt market. However, it is different with Rudangga and Sudiarta [16], Alkhazaleh and Al-Eitan [17] and Hasibuan et al., [18], leverage has a positive effect on firm value. Thus this study provides support for agency theory in terms of how companies manage their debt (leverage).

\section{CONCLUSION}

Based on the results of the data analysis and discussion above, the conclusion in this study is that the PROPER rating and leverage affect on firm value, while carbon emissions disclosure and enterprise risk management disclosure do not affect on firm value. The inability to prove the effect of the two disclosures can be caused by the element of subjectivity in the measurement, because the two disclosures do not yet have a standard set by the regulator. These results indicate that investors take into account external risks in the form of environmental performance based on PROPER ratings and leverage as a manifestation of managerial risk. Thus, the results of this study prove that investors recognize the accountability and independence of PROPER assessments.

\section{REFERENCES}

1. Brigham, E., \& Erhardt, M. (2002). Financial Management, Theory and Practice. SouthWestern.

2. Juwita, R. (2019). The Effect of Corporate Governance and Family Ownership on Firm Value. Review of Integrative Business and Economics Research, 8(1).

3. Kelvin, C., Daromes, F. E., \& Ng, S. (2017). Pengungkapan emisi karbon sebagai mekanisme peningkatan kinerja untuk menciptakan nilai perusahaan. Dinamika Akuntansi Keuangan dan Perbankan, 6(1):1-18.

4. Anggraeni, D. Y. (2015). Pengungkapan emisi gas rumah kaca, kinerja lingkungan, dan nilai perusahaan. Jurnal Akuntansi dan Keuangan Indonesia, 12(2), 188-209.

5. Gabrielle, G., \& Toly, A. A. (2019). The Effect Of Greenhouse Gas Emissions Disclosure And Environmental Performance On Firm Value: Indonesia Evidence. Jurnal Ilmiah Akuntansi dan Bisnis, 106-119.

6. Iskandar, D., \& Fran, E. (2016). The Effect of Carbon Emissions Disclosure and Corporate Social Responsibility on the Firm Value with Environmental Performance as Variable Control. Research Journal of Finance and Accounting, 7(9).

7. Kumar, S., \& Shetty, S. (2018). Does environmental performance improve market valuation of the firm: evidence from Indian market. Environ Econ Policy Study, 20:241-260. 
8. Khlif, H., Guidara, A., \& Souissi, M. (2015). Corporate social and environmental disclosure and corporate performance Evidence from South Africa and Morocco. Journal of Accounting in Emerging Economics, 5(1):51-69.

9. Sarumpaet, S., Nelwan, M. L., \& Dewi, D. N. (2017). The value relevance of environmental performance: evidence from Indonesia. Social Responsibility Journal, 13(4):817-827.

10. Bravo, F. (2017). Are risk disclosures an effective tool to increase firm value?. Managerial and Decision Economics, 38(8), 1116-1124.

11. Louhichi, W., \& Zreik, O. (2016). Corporate Risk Reporting: A Study of the Impact of Risk Disclosure on Firm Reputation. Economics Bulletin, 35(4):2395-2408.

12. Devi, S., Budiasih, I. G. N., \& Badera, I. D. N. (2017). Pengaruh Pengungkapan Enterprise Risk Management dan Pengungkapan Intellectual Capital Terhadap Nilai Perusahaan. Jurnal akuntansi dan keuangan Indonesia, 14(1), 20-45.

13. Agustina, L., \& Baroroh, N. (2016). The Relationship Between Enterprise Risk Management (ERM) And Firm Value Mediated Through The Financial Performance. Review of Integrative Business and Economics Research, 5(1):128-138.

14. Al-Duais, F. (2016). An empirical study on capital structure and corporate performance of chinese listed companies. Journal of Commerce \& Accounting Research, 5(3).

15. Mishra, R. K., \& Kapil, S. (2018). Effect of board characteristics on firm value: evidence from India. South Asian Journal of Business Studies, 7(1):41-72.

16. Rudangga, I. G. N. G., \& Sudiarta, G. M. (2016). Pengaruh ukuran perusahaan, leverage, dan profitabilitas terhadap nilai perusahaan. E-Jurnal Manajemen, 5(7):4394-4422.

17. Alkhazaleh, A. M. K., \& Al-Eitan, G. N. (2017). What Impact do Both Structures of Finance and Costs Have on Firm's Value? A Case Study of Industrial Manufacturing Companies in Jordan. Journal of Economic \& Management Perspectives, 11(4), 296-304.

18. Hasibuan, V., Dzulkirom AR, M., \& Wi Endang NP, N. G. (2016). Pengaruh Leverage dan Profitabilitas Terhadap Nilai Perusahaan (Studi pada Perusahaan Property dan Real Estate yang Terdaftar di Bursa Efek Indonesia Periode Tahun 2012-2015). Jurnal Administrasi Bisnis,39(1), 139-147.

19. Hill, C. W. L., \& Jones, T. M. (1992). Stakeholder-Agency Theory. Journal of Management Studies, 29(2), 131-154.

20. Jensen, M. C., \& Meckling, W. H. (1976). Theory of the firm: Managerial behavior, agency costs and ownership structure. Journal of Financial Economics, 3, 305-360.

21. Luo, J. J., Nelli, C. J., Holverson, T. E., \& Mulroy, A. P. (2014). U.S. Patent Application No. 14/304,388.

22. Ahmad, N. N. N., \& Hossain, D. M. (2015). Climate change and global warming discourses and disclosures in the corporate annual reports: A study on the Malaysian companies. Procediasocial and behavioral sciences, 172(27), 246-253.

23. Nasi, J., Nasi, S., Phillips, N., \& Zyglidopoulos, S. (1997). The evolution of corporate social responsiveness: An exploratory study of Finnish and Canadian forestry companies. Business \& Society, 36(3), 296-321.

24. Suhardjanto, Djoko., Purwanto., Ashardianti, Danti., \& Setiany, Erna. (2018). Environmental Disclosure in Agricultural Sector and Consumer Goods Annual Report (Comparison between Indonesia and Malaysia). Review of Integrative Business and Economics Research, 7(4).

25. Berger, V. (2011). Innovationen und Nachhaltigkeits-Marketing: ein Lehrgang für nachhaltigen Marketingerfolg. EcoLife, 2011(3), 32.

26. Hapsoro, D., \& Ambarwati, A. (2018). Antecedents and consequences of carbon emissions'disclosure: case study of oil, gas and coal companies in non-annex 1 member countries. Journal of Indonesian Economy and Business, 33(2), 99-111.

27. Choi, B. B., Lee, D., \& Psaros, J. (2013). An Analysis of Australian Company Carbon Emission Disclosures. Pacific Accounting Review, 25(1):5879.

28. Nurlis. (2019). Carbon Emission Disclosure in the Proper Rating Company's Annual Financial Statements in Indonesia Stock Exchange. Research Journal of Finance and Accounting, 10(12).

29. Committee of Sponsoring Organization of the Treadway Commission. Di akses pada tanggal 25 September 2019 dari Web: https://www.coso.org/Pages/ermintegratedframework.aspx

30. Mohd-Sanusi, Z., Motjaba-Nia, S., Roosle, N. A., Sari, R. N., \& Harjitok, A. (2017). Effects of corporate governance structures on enterprise risk management practices in Malaysia. International Journal of Economics and Financial Issues, 7(1):6-13.

31. Meizaroh, L. (2011). Emphasizing Corporate Governance and Ownership Concentration on Enterprise Risk Management Disclosures. SNA XIV ACEH.

32. Horne, J. C. V., \& Wachowicz, J. M. (2012). Prinsip-Prinsip Manajemen Keuangan. 13 ed. Jakarta: Salemba Empat. 